The Narrative Gap in Ottoman Armenian History

Author(s): Jeremy Salt

Source: Middle Eastern Studies, Vol. 39, No. 1 (Jan., 2003), pp. 19-36

Published by: Taylor \& Francis, Ltd.

Stable URL: https://www.jstor.org/stable/4284276

Accessed: 24-01-2019 18:36 UTC

JSTOR is a not-for-profit service that helps scholars, researchers, and students discover, use, and build upon a wide range of content in a trusted digital archive. We use information technology and tools to increase productivity and facilitate new forms of scholarship. For more information about JSTOR, please contact support@jstor.org.

Your use of the JSTOR archive indicates your acceptance of the Terms \& Conditions of Use, available at https://about.jstor.org/terms

Taylor \& Francis, $L t d$. is collaborating with JSTOR to digitize, preserve and extend access to Middle Eastern Studies 


\title{
The Narrative Gap in Ottoman Armenian History
}

\author{
JEREMY SALT
}

Early in 2001 French parliamentarians passed a resolution asserting that 'France publicly recognizes the genocide of the Armenians in 1915'.' Similar resolutions have been passed elsewhere in Europe and in the United States and others are being planned. The French decision was taken without any apparent regard for the practical consequences on France's relations with Turkey, where the resolution was received with indignation and anger and (by parties on the right) as further evidence of European hostility towards Turkey. Government contracts with French companies were cancelled and at one university, courses in French dropped from the curriculum. Counter accusations were made against France over the brutality of its occupation of Algeria (1830-1962). There is indeed much to be said about European double standards, hypocrisy and selective morality but it is all beside the point, which remains what happened and why in the Ottoman Empire in 1915.

The Armenian claim is based on massacres which took place in the eastern provinces of the Ottoman Empire during the First World War. The claim of genocide - vehemently denied in Turkey - is based on a reading of history from which the Ottoman narrative is absent except for marginal references in English language sources. This is partly because very few scholars have the language skills necessary to work in the archives, partly because Turkish governments have been slow in releasing archival material on the Armenian question and partly because the amount of material that stands in need of researching before more complete histories can be written is vast. Thus by default most accounts of the Armenian question are still being written almost wholly from European language sources and largely from the archives of two countries - England and France - that were at war with the Ottoman Empire from 1914 to 1918. However, even if these problems of language and access to sources were overcome the Armenian question as presented in Europe and the United States would still stand as a case study of 'history' shaped largely by propaganda and religious bias. The involvement in the Armenian question of religious figures with powerful political connections in the United States and Britain carried over from the

Middle Eastern Studies, Vol.39, No.1, January 2003, pp.19-36

PUBLISHED BY FRANK CASS, LONDON 
nineteenth century into the twentieth. The proposed remaking of the Middle East after 1918 was undertaken partly on the advice received from the religious figures who were regarded as experts on the area. Of the nine members of the King-Crane commission of inquiry despatched to the Near East by the US government after the war to ascertain the political wishes of the local people, five were clergymen. Missionaries had taken a leading role in the propaganda campaign for the Armenians from the late nineteenth century onwards. They did not hesitate to exploit historical antipathy to the Turks and Islam. 'There is no danger of any propaganda making the Americans feel that the Armenians are maltreating the Turks', the leading US missionary figure James L. Barton, who had spent many years in the Ottoman Empire, wrote of the accounts of the killing of Muslims by Armenians during the First World War. 'The idea is universally established here that the Armenians are the worst sinned against of any on the face of the earth and that the chief of the sinners is the Turk backed by the Teuton.' For his American Committee of Armenian and Syrian Relief (ACASR) Barton 'selected writers who were casual about objectivity'. ${ }^{3}$ Through the ACASR missionaries 'flooded the US with anti Turk and pro minority publicity'. ${ }^{4}$

The Ottoman documents already translated certainly cast a different light on the events of 1915. These did not occur in a vacuum. The decision to 'relocate' the Armenians was taken after a year in which Armenian guerilla bands incited and armed by the Russians and organized by the Dashnaks had thrown themselves into the war effort against their own government. Not for the first time in late Ottoman history, some Armenians saw collaboration with the Russians as their best chance of carving an independent state out of the historical Armenian homeland straddling the Ottoman-Russian border. By the Ottoman government they were naturally regarded as traitors. At a time when the Ottomans were fighting a war on several fronts, Armenian guerilla bands were attacking government offices, killing gendarmes and massacring Muslim civilians and burning their villages. Thousands of Armenians were involved in these activities. The fighting between the Russian and Ottoman armies in the eastern provinces was accompanied by ruthless conflict between the local Muslim and Christian population which can be seen as the culmination of decades of simmering tension punctuated by explosions of savage communal conflict. As a matter of military necessity the decision was taken on 27 May to move the Armenian population away from the fighting to districts south of Diyarbakir. The details of how this was to be effected were left to the local authorities. The decision was published as the Provisional Law of Relocations (techir kanunu). Ottoman documents on the relocations - sent in secret and seized by British intelligence in the 1920s after the occupation of Istanbul - included 'strict and explicit rules' on the protection of Armenian lives and property. ${ }^{5}$ Yet on the convoys moving south in the 
direction of the Arab provinces Armenians were set upon and massacred. Wartime deaths through armed conflict, massacre, disease, famine at makeshift camps in Syria (where there was a general famine during the war), along with relocation or emigration to other countries reduced the Armenian community in the Anatolian heartland of the Ottoman empire to a mere remnant. The explanation put out by the Ottoman government in 1916 was that infuriated by Armenian treachery and massacres, the Muslim population 'at last took the law into their own hands'. ${ }^{6}$ Those directly responsible for the killings included roving bands of marauders and soldiers who were supposed to be protecting the Armenians. Revenge because of attacks by Armenian bands on Muslims during the previous year was clearly a motive. The government defended itself by arguing that when it was fighting a war on many fronts it was too hard pressed to prevent these attacks from taking place. The number of Armenians who died during the war remains another controversial aspect of this question. The figure which is often quoted in Armenian propaganda is 1.5 million but this is not supported by estimates made by pro-Armenian sources at the end of the war let alone the figures given by Ottoman historians and Turkish scholars. Sonyel writes that 700,000 Armenians had been relocated by 1917 and that, of the entire Armenian population, about 300,000 died as a result of rebellion, massacre and death through starvation or diseases for which no medicines were available. ${ }^{7}$ The number of Muslims who died during the same period was bound to be much higher than any estimates of Armenian casualties given the numerical preponderance of Muslims to Christians throughout the empire. The president of the Armenian National Delegation, Boghos Nubar, stated in 1919:

Although the losses of the Armenians are very great, those of the Turks in the course of the war have not been less. A German report gives 2,500,000 as the total losses of the Turks by war, epidemics and famine which have caused terrible havoc owing to the improvidence and shortage of hospital personnel and medicines. At least half these losses have been sustained by the population of the Armenian provinces ... which have been invaded both by the Russian and Armenian armies. ${ }^{8}$

Here it should be mentioned that statistics have always been a crucial propaganda aspect of the Armenian question. Estimates of the numbers of Armenians in the Ottoman Empire in the nineteenth century varied greatly according to whether they were provided by the Armenian patriarchate, by the Ottoman government (whose figures were based on the censuses regularly carried out) or by outside observers such as Vital Cuinet. Nor is there any agreement on the numbers of victims of the communal upheaval that overtook the eastern provinces between 1894 and 1896, let alone the tragedy of 1915. Clearly the greater the number of Armenians who could be 
shown to be living in the Ottoman Empire, the stronger the claim that could be made for autonomy or independence; yet in what Boghos Nubar called 'the Armenian provinces' of eastern Anatolia there is no doubt that the Armenians constituted a small minority of the overall population.

A central enigma of 1915 relates to the relocation orders. If the Ottoman government was playing a double game - issuing orders for the protection of Armenians while formulating a policy of massacre - for propaganda reasons these orders surely would have been sent openly, but they were not. They were only discovered by British intelligence officers raking through the Ottoman archives in the 1920s. The original order was reiterated in subsequent instructions. These are genuine documents. If the Ottoman government really had ordered the massacres, why would it send confidential orders to provincial officials instructing them to safeguard the lives of the Armenians during the relocation?

The question of responsibility is pivotal. It is obvious that the relocations would not have taken place but for Armenian collaboration with the Russians in the previous year. Direct responsibility for what happened during the relocations lies with those who actually did the killing and provincial officials who were culpable through direct complicity or indifference or perhaps cowardice (and it here it must be added that many Armenians were saved by being taken under the wing of Muslims). If the central government's self defence is to be taken at face value and there was not a 'policy' of massacre it was still responsible to the degree that it ordered the relocations without having the means to ensure that they were carried out in accordance with its own instructions. Beyond that and beyond the general responsibility of a government for everything that happens within its own territory the picture becomes blurred, but the British intelligence officers who went through the archives in Istanbul found no documentary evidence of a policy of massacre.

A dominant aspect of the Armenian question, like all history, is how it is told, by whom and on the basis of what sources. Up to the present time most narratives of the Armenian question presented to western reading audiences have been based on western sources. There is a received view of Armenian life under Ottoman administration which has been carried forward intact from the nineteenth century. There are good reasons for being sceptical of this presentation of history. First of all, the Ottoman account direct from sources is almost wholly absent, with the policies of the Ottoman government and the views of the sultan and his ministers presented only second-hand through the reports, records and recollections of the European diplomats and travellers with whom they talked. Second, the main archival source for western writers on the Armenian question remain the documents lodged in European archive collections and particularly Britain's 
Public Record Office. These are certainly very valuable but the fact remains that Britain, in particular, was deeply implicated in the development of the Armenian question from the 1870 s onwards, sharply critical of, when not hostile to, Ottoman policies in the nineteenth century and at war with the Ottoman state in 1914-18. In the 1890s worsening relations between Muslims and Christians had already led to a savage communal upheaval of which the Armenians were the principal victims. In England it was the Sultan Abdulhamit II who was made to take the blame when it is clear that whatever the sultan's role, successive British governments were also responsible for pursuing policies that were unworkable and for encouraging the Armenians to strive for goals that were unattainable. Neither can British accounts of what was happening in the sultan's domains always be taken as accurate or impartial. Consuls were often not on the scene of the events they described and relied on informants whose identity they concealed but were almost certainly Armenians or American missionaries and consequently likely to have a biased view of what was happening.

This leads directly to the third area of scepticism in search of truth - the propaganda aspect of the Armenian question from its modern political birth in the nineteenth century until its terrible climax in 1915. Understanding of the Armenian question was enmeshed in European views of the Turks and Islam. The wartime propaganda of the twentieth century was built on the foundations of well established negative views of the Turks. The ostensible British policy from the 1870 s of humanitarian relief of the Armenians through reforms drew support from the broadly held perception of Christian suffering under Muslim rule. The counterweight of Muslim suffering from misgovernment was largely if not wholly ignored and the result was a distortion of the overall picture. Yet it is on the basis of sources that are questionable in their veracity and balance that the modern history of the Ottoman Armenians is still being written.

In the sense of conflicting narratives the events of 1894-96 - when accusations of centrally organized massacres of Armenians were first made against the Ottoman government - stand as a cautionary tale. The 'Armenian Question' had been inscribed on the European diplomatic agenda nearly 20 years before at the Congress of Berlin (1878). The recent war between Russia and the Ottoman state had ended in a Russian victory. The Ottomans had lost most of their territory in south-eastern Europe and the ratification of these losses when the diplomats met in Berlin was one of the most savage blows in their history. Bulgaria was given its autonomy, and European attention now turned to the Ottoman Christians - the Armenians - amongst whom it was thought the Russians were most likely to stir up new trouble not just for the Ottoman government but for the European powers and especially Britain. Russian involvement with the Armenians was 
regarded as a long term threat to British strategic interests further afield. It is this threat - to be regarded within the broader context of Anglo-Russian rivalry covering a vast band of territory stretching from the Balkans to the borders of China - rather than the professed humanitarian concern that dictated official British interest in the Armenians. Under article 61 of the Treaty of Berlin the Ottoman government was obliged to "carry out without further delay the improvements and reforms demanded by local requirements in provinces inhabited by the Armenians and to guarantee their security against the Circassians and Kurds. It will periodically make known the steps taken to the Powers who will superintend their application'. The British pursued the reform question as hard as they could. The grandiose talk in the immediate aftermath of Berlin was of a 'protectorate' over the Armenians but it soon became clear that the most the European governments (and especially the British) could hope to achieve were 'reforms'. Even these met with strong resistance. They were perceived as the first step towards granting the Armenians the autonomy which would then become the foundation for demands for independence.

The Ottoman suspicions were well grounded. The Ottomans were interested in reform themselves but European (and largely British) 'administrative' reforms went against the grain of Ottomanism which was the ruling state philosophy. They were 'ethnographic' in nature. They sought a reduction in the number of eastern vilayets and an administrative separation between Armenian Christians and Muslim Turks, with the Muslim Kurds kept out of the reform plans altogether because of what was regarded as their wild and predatory nature (a great irony considering current European sympathy for the Kurds). ${ }^{9}$ Not only were these 'reforms' intrinsically divisive but among the sultan's Muslim subjects they were seen as an attempt by the European powers to dictate terms to the Ottoman government in the interests of their Christian protégés. By the Armenian revolutionary committees - active in Russia, western Europe and the Ottoman Empire but never representing more than a fraction of the general Armenian population - European interest in reform was regarded as the means by which they could eventually carve an independent state out of Ottoman territories. These committees launched a program of propaganda, assassination and armed uprisings across the eastern vilayets of the Ottoman state. The combination of their provocations, Ottoman suppression and outraged public opinion in Europe ensured that the Armenian question stayed close to the top of the diplomatic agenda. As the situation deteriorated in the six eastern provinces, demands (particularly by missionary boards and other supporters of Christians suffering under the Ottoman 'yoke') to send in the fleet and even occupy the troubled regions became more common. The Cullom Resolution passed by the US Congress called on the President to seek European 
intervention on behalf of the Armenians. The warships San Francisco and Marblehead were sent to Ottoman waters but the more extreme demands were too impractical to be considered seriously on either side of the Atlantic. The fate of the Armenians fitted into a matrix of other issues and by the 1890s European interests had changed. Of the powers mostly closely involved in the Armenian question, Britain had turned its attention away from the Ottoman Empire towards Africa, and Russia towards the far East and the burgeoning power of Japan. Russia also had too many internal problems with revolutionary groups of various stripes to want to give further encouragement to Armenian revolutionary nationalism. The relationship between tsar and sultan - two monarchs on the defensive against an array of internal and external problems - was probably more cordial than it had ever been; as a result, in its dealings with the Ottoman state, Russia would go no further than diplomatic pressure would allow. It would not agree to joint action of a military nature, and if there was to be no joint action there could be no unilateral action either because this might precipitate a scramble for Ottoman territory and thus a European war. Humanitarianism had to give way before hard national interest, but by the time all this became clear communal order in the eastern provinces had collapsed and from all districts came reports of chaos, mayhem and massacre.

Although Britain had played the leading role in igniting the burning trail that led to this powder keg, many in Britain now laid all the blame on Sultan Abdulhamit II, who had in fact been warning for years of the explosion that was likely to follow if reforms were imposed on him which favoured the Armenians and which his Muslim subjects would not accept. But where Christian minorities were concerned it was common in Europe not to take anything said or done by the sultan and his government seriously. The Ottoman reform programme begun decades earlier was dismissed as dust being thrown in Europe's eyes - to quote an expression commonly used at the time - despite all the evidence that the Ottoman government was seriously committed to reforms if not the 'reforms' that the European powers wanted. Thanks largely to the inflammatory rhetoric of the Liberal leader William Gladstone, who had whipped up the 'Bulgarian atrocity' propaganda of the 1870s and tried to do the same for the Armenians in the 1890s, the sultan entered history as Abdul the Damned, Abdul the Assassin and the Red Sultan. In fact, there was no evidence that Abdulhamit was hostile to the Armenians on racial, religious or ethnic grounds. There was no evidence of such animosity towards the Armenians throughout the whole course of Ottoman history but in the wake of the terrible events occurring in the eastern provinces the sultan was turned into a convenient architect of a 'plan of extermination'. Successive British governments published the parliamentary papers (the Blue Books) which have been raked through ever 
since for evidence against the sultan. It is not there. There is hearsay and the whisperings of diplomats in Istanbul who had good reason to cover their own tracks but there is nothing that links Abdulhamit to a policy of massacre. In any case, not all of Britain went along with these accusations against the sultan. The Conservative Prime Minister of the 1890s, Lord Salisbury, refused to accept that the sultan had ordered 'all those cruelties to be perpetrated' and instead blamed 'the race faction and the creed faction driven to the highest point in their corruptest and most horrible form' ${ }^{10}$

Yet the 'policy' of massacre is the theory that still prevails in western histories. Two influential books, Christopher Walker's Armenia: The Survival of a Nation (1980) and Robert Melsom's Revolution and Genocide (1992), deal with the events of 1894-96 in considerable detail. This period begins with the Armenian insurrection in the Talori and Sasun districts of the Bitlis vilayet. There is no doubt that the Armenians of the region were living in deplorable conditions. Their problems included oppression by tax collectors, tax debts, corruption and inefficiency in the Ziraat (Agricultural) Bank which drove them into the hands of loan sharks; bullying and mistreatment by Kurdish aghas and beys and Kurdish troops (the Hamidiye cavalry, the basibazuk irregulars and the militia); the despotic behaviour of the local gendarmerie; a justice system lacking justice that was driving young people in particular into the hands of insurgent bands; and a general level of poverty and population decline brought about by all of the above. This summary was compiled in 1895 by the Department of the General Staff which recommended a series of measures to combat these evils but by then the people of Sasun had risen against the government." In the sequence of cause and effect retold by Walker from the accounts of British consuls stationed near but not in the district, long-standing tension between the authorities and the local Armenian population was brought to a head when a local kaimakam (sub-governor) abused the Armenians for not paying their taxes and was then beaten by them and turned away with his contingent of zaptiyes. Soldiers were sent to the district. Other small incidents took place and at this point Kurds appeared on their annual migration and also came into conflict with the Armenians. 'In at least one case' the Armenians 'reacted' by killing 'several Kurds'. After conferring with the troops the Kurds (the Bekirkanli) fell on two Armenian villages and destroyed them. The villagers fled to nearby mountains and as fighting continued they moved their women and children to the 'greater safety' of Mt Andok. The men took up positions in the village of Geliguzan where they fought 'a ferocious battle over 12 days' with tribal Kurds and soldiers before being driven out by a detachment of Hamidiye cavalry and taking refuge on Mt Andok below the women and children. There, however, soldiers and Kurds broke through their defensive system and killed 'all they could lay their hands on .... The soldiers - a nightmare touch - dressed in black [and] the Kurds in white'. ${ }^{2}$ 
Melson tells a similar if less detailed story of a massacre taking place without any real provocation. ${ }^{13} \mathrm{He}$ repeats (British) Vice-Consul Hallward's claim of 8,000 dead (though Hallward 'had heard higher estimates') while Walker talks of a 'very conservative' low figure of 900 killed up to perhaps a figure of 3,000. ${ }^{14}$ In England Bryce talked of 15,000 being killed. ${ }^{15}$ Most of these figures are gross exaggerations: an Ottoman Commission of Inquiry later found that less than 300 people were killed and even the British consul who was one of the foreign observers permitted to watch the proceedings put the figure at no higher than $900 .{ }^{16}$ As Hallward's reports formed the substance of the allegations made against the Ottoman government it should be noted that they were pieced together far from the scene and furthermore - as Walker observes - from 'second hand and third hand sources'. ${ }^{17}$ Sir Philip Currie, the British ambassador, refers to the 'eye witnesses' and 'trustworthy sources' on whom Hallward relied, ${ }^{18}$ but there is no indication of who these individuals were and consequently no means of appraising the veracity of the claims made. We only have Currie's word, and as Currie was himself the most aggressive proponent of reforms the European governments were trying to impose on the sultan - and an overbearing representative of British power capable of reducing the sultan to tears ${ }^{19}$ - he cannot be regarded as an impartial source himself. He was deeply implicated in the unravelling of the Armenian question and arguably had his own exposed position to protect.

The question of provocation is reduced by both Melson and Walker to a statement by Hallward that while one Armenian revolutionary had been agitating amongst the people of the region in 1893-94 'I do not believe that the agitation amounted to much or had much effect on the villagers' ${ }^{20} \mathrm{Sir}$ Philip Currie accepted this view, writing that an investigation 'would show that statements that the Armenians had risen in insurrection at the instigation of a revolutionary agent were untrue. Such disturbances as had occurred were caused by the attacks of Kurds on the Armenians and the resistance offered by the latter' ${ }^{21}$ Melson writes of the Armenians 'possibly being encouraged' by agitators and of then being 'set upon' by regular soldiers and the Hamidiye cavalry. ${ }^{22}$

These interpretations greatly understate the scale of the revolutionaryinsurrectionist challenge to Ottoman authority being launched across the six eastern provinces in the 1880 s and 1890 s. An entirely different picture of the Talori 'incidents' emerges from Ottoman documents, according to which local villagers rose in revolt in 1894 under the leadership of the Hunchak revolutionary (or incendiary according to the Ottoman government) Hampartsum Boyadjian, who had been agitating amongst the villagers for several years under the field name of Murat. He told them that 'he would bring over a military force from England by balloon after the emergence of an 
uprising since all the states have agreed on protecting the Armenians' ${ }^{23}$ The 'naïve' Armenians of 12 villages were persuaded (others were not) 'and went to a monastery on the top of a mountain nearby after having burned their villages and slaughtered all the inhabitants of all the Mussulman villages on the way and burned their villages too. This is the correct statement of Mourad in his declaration on his cross-examination as reported by the Chief Commander of the Fourth Army Corps' ${ }^{24}$ The picture presented in the Ottoman documents is of a general insurgency in the region, with the Talori rebels joining forces with groups coming from the plain of Muş and the districts of Kulp and Silvan before all of them took up positions on Mt Andok. It was from this stronghold that they launched attacks on Kurdish tribal encampments. In armed clashes there were casualties on both sides but shocking atrocities were also reported to have been committed by the Armenians. (The gory details of these events are also to be found in despatches from the US Minister Plenipotentiary in Istanbul and some foreign newspapers as well as the Ottoman archives). ${ }^{25}$ Military forces were sent to the region to suppress the uprising. Initially, it was thought that 4,000 Armenians were involved: this estimate fluctuated according to the information provided by field commanders but eventually settled at around 3,000. The sultan framed a response to the uprising according to the information he was being sent in daily despatches, most of them from the Commander in Chief of the 4th Army based at Erzurum, Zeki Pasha. Reading through these documents one is able to follow a decision making process shaped from day to day by the events that were happening on the ground. Contrary to the impression given in western histories, the operations in the Talori district were not dominated by the Kurdish Hamidiye cavalry but by the regular army. In fact the role of the Hamidiye was limited. The regular forces sent to the Talori district from the town of Muş, according to a despatch sent from the Department of General Staff to the Imperial First Secretary on 27 August $1894,{ }^{26}$ consisted of an initial contingent of 200 soldiers and four mountain guns from the Fourth Army; three and a half battalions of regular troops sent shortly afterwards; a reserve force consisting of the Eighth Marksmen's Battalion and the second battalion of the 26th Regiment based at Harput. There were 500 troops in each of the reserve battalions. Each other battalion consisted of 800 troops, amounting to a regular army force of about 4,000 troops. By contrast only half a Hamidiye regiment - consisting of 300 men - was sent to take part in the action and not the 'regiments' to which Melson refers. ${ }^{27}$

Thus the forces facing each other in the Talori district consisted of something like 4,300 Ottoman soldiers and cavalry and 3,000 Armenian rebels, some armed with modern weapons but many only with muskets, swords and hatchets. The rebels had apparently planned to attack Muş with the aim of seizing weapons from the arsenal of the reserve militia but 
according to Zeki Pasha were put off by the approach of military forces. Their failure to secure more weaponry spelt the doom of the uprising. In action on and around Mt Andok that extended through August until early September the rebels were crushed and their leaders captured and later interrogated. Their losses (dead or wounded not specified) are given as around 1,000, with their Hunchak leader and 11 of his followers being captured in a cave. ${ }^{28}$ The Ottoman archives record that women, children and the elderly who had taken refuge on Mt Andok or who had joined the rebels gradually returned to their villages and were given food and clothing 'and all kinds of help on Islamic and humanitarian principles'. Zeki Pasha wrote that he had witnessed this himself. ${ }^{29}$ Accusations of the rape of women and massacre of civilians are vehemently denied.

The question of what Walker and Melson call 'provocation' over the 1894-96 period is an important one. The activities of the revolutionaries from the 1880s onwards included assassination (of Ottoman officials and Armenian 'traitors') and the instigation of a number of uprisings, yet both Walker and Melson manage to dismiss provocation as a serious factor (it 'falls short of being a credible explanation' for the massacres according to Melson $^{30}$ ) and thus other 'real' reasons have to be found. The trail leads directly to Yildiz Palace. Melson quotes some extremely partisan sources, including Johannes Lepsius, who believed (in Melson's words) that the massacres which took place between 1894-96 were 'initiated by the Porte, that is the regime of Abdul Hamid II from Constantinople'. ${ }^{31}$ Why the sultan would want to 'initiate' or 'tolerate' massacres of the Armenians is put down to the fact that he was 'a deeply conservative if not reactionary head of state who wanted to preserve his empire even at the cost of severe repression' ${ }^{32}$ (unlike, of course, every other European monarch of the nineteenth century). Another reason, projected against a background of internal disintegration, is the sultan's desire to 'guard the old order and revitalize Islam' and to protect 'his most sacred values' against the challenge represented by the Armenian social, economic and cultural renaissance which was 'altering the relative status between them [the Armenians] and their Ottoman superiors' ${ }^{33}$ (Such a comment reveals a basic misunderstanding of social stratification within Ottoman society. As Roderic Davison has observed of the class relationships in Ottoman society: 'The line of basic demarcation ... ran not between Muslim and Christian, Turk and non-Turk but between ruler and ruled, oppressor and oppressed. Those on top - whether Ottoman civil servants or army officers, Greek or Armenian bankers or merchants or higher ecclesiastics - looked down on the masses. ${ }^{34}$ These Armenians would have had no hesitation in describing themselves as Ottoman Armenians.) Yet another possible reason - taken from the writings of Edwin Pears - is the sultan's presumed 'irrational hatred' of the Armenians. ${ }^{35}$ 
Melson's overall emphasis is on the threat posed by the Armenians to the traditional hierarchical order; there was a policy of massacre or at least massacre was 'used or acceded to by the regime' ${ }^{36}$ to restore this order and if the sultan did not proceed from massacres to extermination or 'total domestic genocide' in the 1890 s it was because 'he was a reactionary conservative who opposed radical transformations of state and society. Indeed, to commit genocide by destroying the Armenian millet would have been a radical departure from the sultan's ideology and it would have undermined Islam and the millet system as myths of legitimation linking the Ottoman state to Ottoman society. ${ }^{37}$

Melson's case for a 'policy' of massacre is built on the stepping stone of one supposition after another and yet it is this structure that serves as the foundation for his case that the 'policy' of massacres of the 1890s was the prelude to the 'genocide' of 1915 . His suppositions about what was going on in the sultan's mind have no basis in fact or in what is known of the sultan's character. The sultan was suspicious (to the point of paranoia according to his detractors) but there is no evidence that he hated Armenians as an ethno-religious group (as much as the activities of the revolutionary committees clearly infuriated him) and neither is there any evidence that he ever contemplated massacring them. To put such a sequence of thoughts into the sultan's mind is lèse-history on a grand scale. The observations that the sultan was conservative, that he wanted to protect the existing order and that he had a deeply religious nature and sought to enhance or 'revitalize' Islam within the Ottoman state and beyond its boundaries are no basis for an indictment against him. Abdulhamit was a man of his time and cannot be judged outside it. There was not one European monarch who could not be described in similar terms. They were all religious and conservative and anxious to strengthen the dominant religion (Christianity in their case) within their own countries and to bring its benefits to others as well. In this sense Abdulhamit was entirely unexceptional. Did he oppose revolutionary movements? He certainly did, but so did they all. Whether these groups were Muslim (the Young Turks) or Christian (the Armenians and the Macedonians) was beside the point. It was revolution that he opposed. As for the Armenian renaissance it was the Ottoman government itself which encouraged the modernizing reforms of the Armenian millet in the nineteenth century. There is no evidence that the sultan was resentful of the Armenians for economic or social reasons although there is some evidence that his Muslim subjects were. The amira class was close to the palace and indeed the leading Armenian families established much of their wealth on the basis of this connection. They served in the bureaucracy and mixed in the same court circles as the sultan's Muslim pashas: in general the nature of the relationship between the sultan and the Armenians close to the palace 
bears out the observations made by Davison. What can be said without any doubt is that Abdulhamit was determined to repress any movement which threatened to bring about the further disintegration of the empire. That was his responsibility as the sultan. If Armenian autonomy - almost certainly leading to demands for an independent state - is to be regarded as part of the 'Armenian renaissance' he would oppose it to the limit of his powers. Was there any other European monarch who would not have done the same in the face of an internal uprising?

Melson includes the Armenian peasants of the eastern vilayets in the Armenian 'renaissance'. Instigated (or incited) by revolutionary activists there is no doubt that many peasant villagers underwent a form of national awakening but in its broader cultural sense the word would be misapplied. In Europe it was common to think of the Armenians as the 'Europeans of the east' but the sophistication of the cities was not to be found among either Muslims or Christians in the distant parts of the Ottoman Empire and Armenian priests could be just as narrow minded and fanatical as Muslim imams. The general level of education was low and it was precisely on ignorance and fanaticism that the revolutionaries traded, convincing Armenian villagers before the uprising in the Talori district in 1894 that British troops were about to come to their rescue in balloons and then leading them in attacks on Muslim villages. The allusion to the Armenians as being the 'wretched of the earth' ${ }^{38}$ singles them out from the rest of the population in their suffering yet there is a mass of evidence even in the British Parliamentary Papers to show that problems from misgovernment were just as much the lot of Muslims. An argument can even be made that in many respects the Muslims were worse off, carrying the truly onerous burden of conscription (from which Christians were exempt) and living in just as much hardship in their remote eastern villages as the Christians, but in the nineteenth century the problems of Muslims were generally invisible to the outside world. The Christian world was concerned about Christians and only about pagans, heathens and Muslims when it was thought that there was some chance of converting them. This singling out of a minority and the corresponding invisibility of the Muslim majority are two of the strongest characteristics of western 'orientalist' attitudes towards the Middle East from the nineteenth century up to the present time.

What is more significant than any of the suppositions and opinions linking the values and dislikes of the sultan to the ultimate supposition of a government policy of organized massacres is what was actually happening or what was believed to be happening in the eastern provinces (perceptions strongly shaped by gossip and rumour spreading from town to town and village to village being almost as important as the events themselves). All the evidence suggests that the revolutionary/insurrectionist movement 
constituted a threat to social order somewhere along the plane between substantial and serious, and possibly constituted a threat to the integrity of the empire itself given the involvement and interests of the European powers. The active members of the revolutionary movements might have been few in number but they were well organized in cells across the six eastern provinces and they were capable of rousing hundreds if not thousands to their cause. Figures have been given for the rising in the Talori district. Hundreds were involved in a revolt at Van and far greater numbers were caught up in the Hunchak-directed uprising which took place at Zeitun in 1895. This was a well planned, well organized and bloody affair which lasted from late summer until a settlement was finally negotiated with the rebels in January 1896 through the mediation of the consuls of the foreign powers. The Ottoman government estimated that 12,000 - 14,000 Armenians were involved in the uprising. ${ }^{39}$ About 18,000 Ottoman troops - regular soldiers and redifs (reserves) - were sent to the region to lay siege to the town. Zeitoun had a long history of turbulence, rebellion and resistance to the payment of taxes on the grounds of the poverty of the people. A British military consul visiting the town in 1881 wrote that the Zeitunlis were

a semi-barbarous and depraved community, little better than savages and so ignorant, self-opinionated and conceited that it is impossible to do any good with them by argument or persuasion. Strongly convinced that they are a power of themselves, that the Turkish government is afraid of them, very excitable, reckless, idle to a degree and utterly ignorant of what goes on outside their own mountains they are now in such a state that I can hardly conceive that order can be restored without bloodshed. ${ }^{40}$

The uprising began when rebels overwhelmed the government building and the town garrison and took hundreds of people prisoner, including the kaymakam (sub-governor) and 600 soldiers and 50 officers. Almost all the captured soldiers were subsequently massacred (by the women of Zeitun according to one account). The rebels then spread rebellion throughout the region: according to a decree from the Office of the Imperial Secretariat at the Palace to the Cabinet

Through the disclosures made in this telegram [from the governor of Aleppo] it is evident that the insurgents have burnt down numerous Muslim villages and killed many Muslim children. They furthermore cut off the breasts of Muslim women and committed mass murders of the Muslim folk who could not escape. The insurgents were not content with these barbarous deeds and through the help of their own populous crowd they killed a big portion of the soldiers in the barracks at Zeitoun, 
in fact according to a rumour all the soldiers except one or two officers, and seized weapons such as guns and rifles and military equipment and ammunition. According to the latest available information it is understood that a very small number of soldiers in the barracks are alive. ${ }^{41}$

By any standards this was a major uprising. The timing was significant. The uprising began while the sultan was considering the latest 'reform' proposals put to him by the powers. He finally accepted them in a limited form on 17 October. Outlining measures for better government that would bring greater numbers of Armenians into the provincial administration, they were issued in the form of an irade and were not described as reforms but as 'orders to enforce existing laws or regulations in harmony with them' ${ }^{42}$ They were not officially published until November 1896 which can be taken as a sign of Abdulhamit's sensitivity to their probable effect on Muslim public opinion. In any case, once they became common knowledge they were regarded as a victory by the Hunchaks, at least as a limited victory by the British government which had led the pressure for reform and as a disaster by Muslims. The three months which followed were the bloodiest of the threeyear period from 1894-96.

In short it cannot credibly be argued that the revolutionary parties did not represent a serious threat. Their influence was not just to be measured by the destabilising effects of their activities on social order but by the possibility that the sultan could be forced through European pressure to set up a segregated 'ethnographic' administration in the eastern provinces. As understood by Abdulhamit such an ethno-religious Armenian enclave would be a stepping stone first to autonomy (along the lines of the autonomy granted, under European pressure, to the Maronites of Mt Lebanon in 1864 and the Bulgarians in 1878 under European pressure) and finally independence.

Although British pressure for reforms was cloaked in humanitarian concern it was intensely political and predominantly self serving. The intention after the Congress of Berlin was to block the spread of Russian influence. The British were alarmed that the Russians would annex 'Armenia' and use it as the base to threaten Britain's strategic position in the region and as far afield as India. British involvement in the affairs of the Armenians was regarded as a strategic necessity. A 'protectorate' over the Christians in the eastern vilayets would have greatly strengthened the British position on the ground near the Russian border. It soon became clear that there was no chance that the sultan would accept such a project but 'reforms' in the eastern vilayets might do almost as well. As originally envisaged by the British these reforms would have been supervised by British consuls and judges overseeing all aspects of the administration including tax collection, the police and the court system. Quite clearly the whole arrangement would 
have undermined the sovereignty of the sultan within his own domains and for that reason he was bound to resist it. He had no intention of allowing what remained of his empire to be lost through internal agitation fed by outside involvement. No European monarch would have acted any differently and it is in this context that his reaction to the rise of the Armenian revolutionary movement and the machinations of European governments should be understood and not through imaginative references to his sacred values. The sultan was fully aware of the shortcomings of his provincial administrators. He was autocratic but he was not hostile to reforms as any study of late Ottoman history will show. He drew up his own proposals after Berlin but no reform plan was likely to succeed against the background of violence and disorder that began sweeping the Ottoman provinces from the 1880s.

The gap between alternative narratives of the events that took place in the 1890 s is vast. Official documents always have to be read sceptically but this applies to British documents as well as the Ottoman. Hallward wrote the reports which inflamed opinion in England on the basis of second-hand information. So did Vice Consul Fitzmaurice whose graphic account of the burning of the Armenian church at Urfa was penned many months after the event. There is also the question of the political use of the British parliamentary papers (the 'Blue Books'). Governments usually have a reason for publishing some documents and withholding others and the British government was unlikely to be any different. By insinuating in despatches that the sultan was to blame, was it trying to protect itself from responsibility for the disastrous consequences of its own failed policies? In addition there was the religious bias which permeated popular and parliamentary discussion of the Armenian question. The terrible dénouement of the Armenian question in the 1890s seemed proof of what was already known about Islam and the awfulness of the Turks. No further questions needed to be asked. Gladstone was still a powerful public figure, agitating for the rights of Christians in the Ottoman Empire as he had been doing since before the Congress of Berlin. Although he denied having any special animus against the sultan or Islam it is quite clear that he did, that he loathed the sultan (of whom he wrote venomously in his diaries) and that he shared the antagonistic Christian view of Islam as a religion and of the Turks as a people, whom he had described in the 1870 s as being, 'from the first black day they entered Europe, the one great anti-human specimen of humanity'. ${ }^{43}$ Views such as his - coming out of centuries of adversarial religious history - were shared by influential figures within or close to the British government as well as by missionaries and by Christian opinion generally on both sides of the Atlantic.

It was only 20 years until 1915 and attitudes had not changed in that time. Many of the political and religious figures who had agitated for the Armenians in the nineteenth century (Bryce being the most influential of 
them) were still on the scene. Again the Armenian question became a propaganda weapon: in the hands of the Armenian national movement, trying to secure support for a state to be carved out of the eastern Ottoman Empire when the war was over; in the hands of the governments locked in war with Germany and the Ottoman state; and in the hands of the missionaries and religious humanitarians who had been fulminating against the evils of Islam and 'Muhammadan government' for decades, and for whom Christian suffering at Muslim hands was inevitable.

Now there are genocide and counter-genocide allegations. In the case of the resolution passed in France the practical damage done to diplomatic and trade relations with Turkey has already been noted. As three French commentators have observed, the negative effects within Turkey include the weakening of pro-EU Turks and the strengthening of the 'militarynationalistic clique'. ${ }^{44}$ This is all politics but the historical question cannot be ignored. The central problem from the standpoint of history remains the sources on which the western historical narrative is still being written. The Ottoman archives remain largely unconsulted. When so much is missing from the fundamental source material, no historical narrative can be called complete and no conclusions can be called balanced. If the Ottoman sources are properly utilized, the way in which the Armenian question is understood is bound to change but from such close scrutiny no one is likely to emerge with unstained hands - not Turks or Kurds responsible for the killings, not the Armenians who engaged in revolt against the Ottoman government and were themselves guilty of massacres, and certainly not the European governments playing minority politics in the Middle East in time of peace and in time of war from the nineteenth century until the present. There is unlikely to be a pristine version of history that neatly accommodates the foundation myths necessary to Armenian nationalism. The search for 'truth' will probably remain chimerical but is more likely to lead somewhere if left to historians rather than politicians and lobbyists.

\section{NOTES}

1. On 18 Jan. 2001.

2. J.L. Grabill, 'Missionaries amid Conflict: Their Influence upon American Relations with the Near East 1914-27' (Unpublished Ph.D thesis, Indiana University, Bloomington IN, 1964), p.80 (UMI Dissertation Services, Ann Arbor MI, 1997).

3. Ibid., p.38.

4. Ibid., p.40.

5. Salahi Ramsdan Sonyel, The Ottoman Armenians: Victims of Great Power Diplomacy (London: K. Rustem and Brother, 1987), p.300.

6. Ibid., p.305.

7. Ibid., p.300. A useful table of comparative figures is to be found in Youssef Courbage and Philippe Fargues, Christians and Jews Under Islam (London: I.B. Tauris, 1997), pp.126-7. Arnold Toynbee arrived at a figure of between 460,000 and 860,000 Armenian dead. The German pastor Johannes Lepsius put the number at between 996,000 and $1,046,000$. The 
Ottoman scholar Justin McCarthy, who has specialized in demographics, estimated that 584,000 Armenians died.

8. Ibid., p.301.

9. See Jeremy Salt, 'The Ambassadors Propose', Imperialism, Evangelism and the Ottoman Armenians 1878-1896 (London and Portland, OR: Frank Cass, 1993), Ch.7.

10. Ibid., p.2.

11. Ottoman Archives. Yildiz Collection, The Armenian Question, Vol.II (Istanbul: Historical Research Foundation, 1989), p.285ff, from Department of General Staff to Prime Ministry on 'administrative, economic and military measures to be taken in order to relieve tension around Bitlis, Mush and its vicinity'.

12. Christopher J. Walker, Armenia: The Survival of a Nation (New York: St Martin's Press, revised 2nd edition, 1990), p.141.

13. Robert Melson, Revolution and Genocide: On the Origins of the Armenian Genocide and the Holocaust (Chicago and London: University of Chicago Press, 1992), pp.41-69.

14. Walker, Armenia, p. 142.

15. Salt, Imperialism, p.75.

16. Ibid., p.75.

17. Walker, Armenia, p.143.

18. Bilal N. Simsir (ed.), British Documents on Ottoman Armenians, Vol.III, 1891-95 (Ankara: Turkish Historical Society, 1989), p.395, no.281, Sir Philip Currie to the Earl of Kimberley, Therapia, 4 Nov. 1894 , inc. no. 1 .

19. Salt, Imperialism, p.152. The sultan believed that Currie was a 'wicked man'.

20. Melson, Revolution, p.45.

21. British Documents, p.396.

22. Melson, Revolution, p.44.

23. Ottoman Archives, Vol.I, coded telegram 16 Sept. 1894, Zeki Pasha (commander in chief in the Fourth Army) to Ministry of National Defence on 'ongoing military operations to suppress the uprising at Talori and a report of the latest situation'. See also Salt, Imperialism, p.74.

24. Salt, Imperialism, p.74.

25. See United States National Archives (USNA) despatches from US Ministers to Turkey 1818-1906 (microcopy T46), Constantinople Legation, No.351, 4 Dec. 1804, Terrell to Gresham, reporting a discussion with Abdulhamit.

26. Ottoman Archives, Vol.I, p.183.

27. Melson, Revolution, p.45. Plans to send three companies of Hamidiye to Talori were dropped once information had been received that the insurgents had been 'completely overpowered'; Ottoman Archives, Vol.I, p.237. Imperial First Secretary to Department of General Staff, 2 Sept. 1894.

28. Ibid., p.307, 4th Army Command to Department of General Staff, 18 Sept. 1894.

29. Ibid., p.299.

30. Melson, Revolution, p.51.

31. Ibid., p.47.

32. Ibid., p.53.

33. Ibid., p.61.

34. Salt, Imperialism, pp.22-3.

35. Melson, Revolution, p.63.

36. Ibid., p.67.

37. Ibid., p.69.

38. Ibid., p.67.

39. Ottoman Archives, Vol.II, see Imperial Decree, Office of the Imperial Secretariat (Yildiz Palace) to the Cabinet on 'the Armenian uprising at Zeitoun and the measures to be taken against the intervention of foreign states during [the] quelling [of] the rebellion', p.377ff.

40. Salt, Imperialism, p.60.

41. Ottoman Archives, Vol.II, p.381. See also Esat Uras, The Armenians in History and the Armenian Question (Istanbul: Documentary Publications, 1988), pp.746-55.

42. Salt, Imperialism, p.93.

43. W.E. Gladstone, The Bulgarian Horrors and the Question of the East (London: J. Murray, 1876), p.9.

44. See Libération, 9 Feb. 2001, p.5, Alain Dugrand, Jeran Keyahan and Gilles Perrault, 'Paris a désservi les Turcs démocrates'. 